\title{
RADIOCARBON ANALYSIS OF MODERN SKELETAL REMAINS TO DETERMINE YEAR OF BIRTH AND DEATH - A CASE STUDY
}

\author{
G T Cook ${ }^{1,2} \bullet$ L A N Ainscough ${ }^{3} \cdot$ E Dunbar $^{1}$
}

\begin{abstract}
To aid in the development of a biological profile for human remains found in Collyhurst (Manchester, England), we undertook radiocarbon analysis of tooth enamel, tooth collagen, and bone collagen on behalf of the Greater Manchester Police. On the basis of the analyses of the teeth, we concluded that the person was born between 1950 and 1954, while on the basis of our analyses of cortical and trabecular bone we estimated the year of death to be between 1969 and 1974. This would make the maximum age range around 15 to $24 \mathrm{yr}$. Analyses of the dentition and other skeletal parameters can eliminate the younger part of the range, so an age of around 18 to $24 \mathrm{yr}$ at death would seem most likely. The $\delta^{13} \mathrm{C}$ and $\delta^{15} \mathrm{~N}$ values for the bone collagen were higher than would be expected for someone subsisting on a purely terrestrial diet, implying some consumption of marine resources, which could lead to reduced ${ }^{14} \mathrm{C}$ activities. Taking any potential marine effect into account could reduce this age range to around 18 to $21 \mathrm{yr}$.
\end{abstract}

\section{INTRODUCTION}

A major role of a forensic anthropologist is establishing the identity of a deceased individual through the creation of a biological profile, often based solely on skeletal remains. A biological profile is comprised of the estimation of four major criteria, namely, biological ancestry (Negroid, Caucasoid, Mongoloid and Australoid); sex (two methods: metric and nonmetric); stature; and age at death. In terms of any police investigation, the determination of age at death is particularly important as a precise and accurate assessment will help to eliminate certain individuals from a missing person enquiry, but in contrast, it may highlight others who could require further investigation. While a relatively accurate age at death can be achieved for juveniles (Reventlid 1996; Scheuer and Black 2000), a similar determination made on adult remains is considerably less accurate, particularly in the post-40-yr age range. This can be further complicated by the passage of time whereby certain key elements of the remains may become damaged or lost, e.g. by excavation equipment when the remains are discovered or by scavenging animals. In such cases, the anthropologist is often only able to make very broad statements such as "mature adult." In the past decade in particular, it has been recognized that radiocarbon contained in modern human skeletal remains has significant potential to contribute to the establishment of a biological profile by providing estimates of years of birth and death. This is achievable because it decays at a known, fixed rate and its levels can be related to the wellconstrained atmospheric nuclear weapons testing peak that sits above the natural production level.

Taylor et al. (1989) proposed that three time periods could be assigned to the recent past: (1) a pre-1650 period they termed "non-modern," (2) the period from 1650-1950 termed "pre-modern," and (3) a post-1950 period termed "modern." It could be argued that, more correctly, for forensic studies, pre-modern should be AD 1650 to 1955 and modern should be post-AD 1955 since it is only from post- 1955 that fraction modern values $>1$ are observed and hence the remains can be unambiguously assigned to the modern period. Taylor et al. (1989) demonstrated that in the absence of other information, use of single ${ }^{14} \mathrm{C}$ measurements on bone collagen from juveniles and adults can provide limited information, i.e. whether or not the person died during the nuclear era. However, more recently, Ubelaker and Parra (2011) studied four individuals of varying age at death $(16,27$, 44, and 56 yr) from Andean Peru. In the youngest individual, they found no ${ }^{14} \mathrm{C}$ lag between the atmospheric activity during the year of death and the activity in the collagen of both cortical and trabecular bone. In the three older individuals, they found significant lags $(\geq 11 \mathrm{yr})$ between death and the ${ }^{14} \mathrm{C}$ formation value of cortical bone but minimum lags between trabecular bone formation

1. SUERC, Scottish Enterprise Technology Park, Rankine Avenue, East Kilbride G75 0QF, UK.

2. Corresponding author. Email: Gordon.Cook@glasgow.ac.uk.

3. Cellmark Forensic Services, Unit B1, Buckshaw Link, Ordnance Road, Buckshaw Village, Chorley, Lancashire PR7 7EL, UK.

Proceedings of the 1st International Radiocarbon in the Environment Conference 18-22 August 2014, Queen's University Belfast, Belfast, Northern Ireland, UK

Edited by Evelyn Keaveney and Paula Reimer 
and death. Although this is a very limited data set, it strongly suggests that ${ }^{14} \mathrm{C}$ analysis of trabecular bone may provide a more accurate estimate of age at death for people aged up to their mid-50s.

In teeth, the enamel component contains $<1 \%$ carbon as carbonate within the apatite structure. There is no turnover of this carbon and it has been demonstrated that the ${ }^{14} \mathrm{C}$ activity reflects that of the atmosphere close to the time when enamel formation was occurring (Spalding et al. 2005). Since the crown of each tooth forms at a well-defined time in relation to birth, it is possible to establish the year of birth for someone born between the early 1950 s and present day from ${ }^{14} \mathrm{C}$ measurements made on this carbonate component and comparison of the activities with the well-constrained nuclear weapons peak. The ambiguity regarding which side of the peak the activity relates to can be resolved by measuring the ${ }^{14} \mathrm{C}$ activity in enamel from two teeth that form at different times. Spalding et al. (2005) were able to determine year of birth to within $1.6 \pm 1.3 \mathrm{yr}$ using this technique. Cook et al. (2006) proposed an alternative method for resolving this ambiguity using a single tooth. They proposed that since amino acid racemization had demonstrated a lack of carbon turnover in the root, they could make an additional ${ }^{14} \mathrm{C}$ analysis on the collagen from the combined dentine and cementum. Since the crown enamel always forms before the root, this provides the temporal offset required to determine which side of the bomb peak the ${ }^{14} \mathrm{C}$ enamel activities belong. A full discussion of the application of ${ }^{14} \mathrm{C}$ analyses of teeth and bone for forensic analysis can be found in Cook and MacKenzie (2014).

Over the past few years, the SUERC laboratory has dealt with an increasing number of submissions of human remains from police forces and forensic science companies throughout the UK. During this time, a close working relationship has developed between the SUERC laboratory and Cellmark Forensic Services. In many instances, the submissions have comprised single bones such as crania, femurs, and tibias, and in the majority of these cases, the results of the ${ }^{14} \mathrm{C}$ analyses demonstrated that the remains were either non-modern or pre-modern. However, on occasion, whole, or close to whole, skeletons are discovered in situations strongly suggesting that the remains are likely to be of someone who died during the nuclear era. The following is a case study of such a set of remains.

\section{CASE STUDY}

In January 2010, human remains were found in a disused car park, off Angel Street, Collyhurst, in the city of Manchester, England, by workmen excavating the site in preparation for building construction. They were discovered in a 1-m gap between an old wall and 3-m-high hoardings fixed to concrete posts. Greater Manchester Police undertook a thorough crime scene investigation, utilizing the skills of a forensic archaeologist and a forensic anthropologist at the scene. The majority of the skeleton was recovered, though some parts were missing while others were damaged (Figure 1). Subsequently, there was a joint postmortem examination by a forensic pathologist and the forensic anthropologist. The death was being treated as suspicious due to the location of the remains and evidence of trauma on the skeleton, which could possibly indicate a violent assault. From the anthropology examination, the following facts were established:

1. Biological ancestry: The predominant contribution to ancestral traits appeared to be Caucasoid with a potential Negroid contribution.

2. Estimation of sex: The diagnostic pelvis was damaged but skull observations and metric analysis of the cranium indicated that the remains were of a female but the characteristics were not hyper-feminine.

3. Estimation of living stature: Femur and tibia length measurements were applied to a wellestablished formula to estimate the height of the deceased. It was estimated that this person was between $5^{\prime} 3^{\prime \prime}$ and $5^{\prime} 6^{\prime \prime}$ in height. 
4. Estimation of age: This is a critical element in establishing the profile but perceived as the most unreliable. Typically, the forensic anthropologist will use as many indicators as possible to build up a picture of an age estimate; however, the Manchester remains were challenging as there were a limited number of areas to observe due to loss and damage. The inclusive age range was estimated as 18 to $75 \mathrm{yr}$. However, epiphyseal fusion would tend to suggest that this individual was at the lower end of this range, with one method estimating the maximum age for a female as 27. On this basis, females between 18 and 30 were deemed to be of the highest priority in the missing persons' investigation.

A DNA profile was obtained from the bone and was searched against the UK Missing Person DNA database and the National DNA database with no result. Enquiries by Greater Manchester Police, tracing persons who were reported missing at the relevant time and analyzing DNA from relatives, again did not provide a result.

The laboratory was contacted in early 2011 for advice on whether ${ }^{14} \mathrm{C}$ measurements might provide additional information on the remains, such as year of birth, confirmation of age at death, etc. Over the next 3 years, we carried out a series of ${ }^{14} \mathrm{C}$ measurements on various individual elements of the remains.

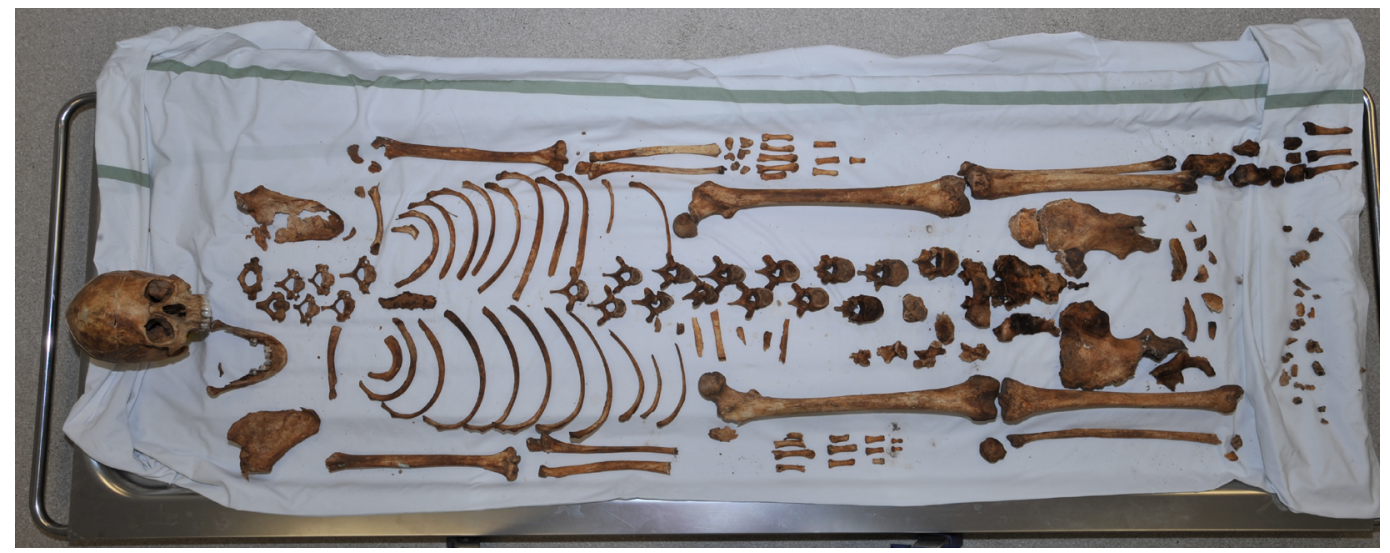

Figure 1 Human remains from Collyhurst, Manchester

\section{METHODS}

\section{Bone Collagen Preparation}

Collagen samples were prepared using a modification of the Longin (1971) method. Subsamples were cut from the bones and the surfaces cleaned to remove any adhering soil and contaminant material using a Dremel ${ }^{\circledR}$ multitool. Some $100 \mathrm{~mL}$ of $1 \mathrm{M} \mathrm{HCl}$ were added to each and allowed to react for a minimum of $24 \mathrm{hr}$ to dissolve the apatite, after which, the bone material should appear "jelly like." The excess acid was decanted and $100 \mathrm{~mL}$ of reverse osmosis water were added and the samples heated in a sand bath at $\sim 80^{\circ} \mathrm{C}$ for $3 \mathrm{hr}$. When the bone collagen was completely solubilized, the solutions were allowed to cool and filtered through GF/A filter paper. The collagen filtrates were dried down to $<20 \mathrm{~mL}$ and transferred to weighed vials. The vials were transferred to a freeze-drier until the solutions were completely removed and the collagen was left as a crystalline powder. Subsamples of the collagen were combusted at $850^{\circ} \mathrm{C}$ in sealed quartz tubes according to the method of Vandeputte et al. (1996). The evolved $\mathrm{CO}_{2}$ samples were cryogenically purified and 3-mL volumes were graphitized according to the method of Slota et al. (1987). Further subsamples of collagen were taken for $\delta^{13} \mathrm{C}$ and $\delta^{15} \mathrm{~N}$ analyses by continuous-flow isotope ratio mass spectrometry. 


\section{Tooth Enamel Preparation}

The enamel was isolated using a modified version of the method described by Spalding et al. (2005). The required minimum weight of a tooth is $0.5 \mathrm{~g}$. This is placed in a beaker to which $100 \mathrm{~mL}$ of ultrapure water are added and the beaker placed in a sonic bath for $5 \mathrm{~min}$ to remove any adhering soft tissue. The sample is then rinsed and the process repeated if necessary. Using a Dremel multitool, the tooth crown is removed from the root, cut lengthwise in half, and the internal dentine material removed as far as possible from each section using a dissecting needle. (The root section is reserved for collagen extraction.) The crown is placed in $10 \mathrm{M} \mathrm{NaOH}$ solution, heated on a hotplate at $80^{\circ} \mathrm{C}$ for $8 \mathrm{hr}$, allowed to cool and the dentine scraped from the enamel, again using a dissecting needle. This process is repeated until all the dentine has been removed from the enamel. The separated enamel is repeatedly rinsed with $0.5 \mathrm{M} \mathrm{HCl}$ to remove residual $\mathrm{NaOH}$ and finally rinsed with distilled water before being oven-dried overnight.

The prepared tooth enamel is weighed into the main body of a small $100-\mathrm{mL}$ hydrolysis unit and $20 \mathrm{~mL}$ of $15 \mathrm{M}$ orthophosphoric acid are added to the side arm of the unit. The hydrolysis unit is connected to a vacuum line and pumped under vacuum for 5-10 min. The tap on the hydrolysis unit is then closed and the unit removed from the vacuum line. The phosphoric acid is added to the tooth enamel and left to react in a fume cupboard for $24 \mathrm{hr}$. The hydrolysis unit is then reconnected to a vacuum line and the $\mathrm{CO}_{2}$ is isolated, cryogenically purified, and 1-mL subsamples are graphitized according to the method of Slota et al. (1987). Typically, the carbon content of tooth enamel is $\sim 0.4 \%$.

\section{Tooth Collagen Preparation}

Dentine comprises $\sim 75 \%$ inorganic material (mainly hydroxyapatite) and $25 \%$ organic (mainly collagen). Cementum comprises $70 \%$ mineral material (again mainly hydroxyapatite) and $30 \%$ organic (mainly collagen) (Mays 1998). The roots were immersed in $1 \mathrm{M} \mathrm{HCl}$ for $\sim 48 \mathrm{hr}$ to effect total demineralization, washed in reverse osmosis water, and then placed in beakers containing $\sim 50 \mathrm{~mL}$ of reverse osmosis water and heated for $\sim 3 \mathrm{hr}$ at $80^{\circ} \mathrm{C}$ to dissolve the collagen. The samples were then filtered through GF/A paper and heated to reduce the volume to $\sim 5 \mathrm{~mL}$, at which point they were freeze-dried. Subsamples of the collagen were treated as described above for bone collagen.

\section{AMS Analysis}

${ }^{14} \mathrm{C}$ measurements on the graphite preparations were undertaken using either our $5 \mathrm{MV}$ terminal voltage tandem accelerator mass spectrometer or our $250 \mathrm{kV}$ single stage accelerator mass spectrometer (SSAMS), both manufactured by National Electrostatics Corporation. These spectrometers feature high-intensity sputter ion sources with 134-sample capacity. Samples are measured to completion in groups of 10 with each group containing (i) one oxalic acid II primary standard, (ii) one humic acid secondary standard of less than 1 half-life in age (used in two international intercalibration studies: C-14 Cross-check and VIRI), (iii) either a modern secondary standard material (TIRI barley mash) or a background standard (interglacial wood, infinite-age bone, or geological carbonate depending on the type of unknowns being measured), and (iv) seven unknowns. The oxalic acid II primary standards effectively span the groups to provide intergroup consistency. Each sample is automatically, repeatedly measured in intragroup rotation until the total counting statistics and the scatter of the repeat ${ }^{14} \mathrm{C} /{ }^{13} \mathrm{C}$ measurements is better than $3 \%$, disregarding early inconsistent measurements as necessary. Finally, time trends in the completed data sets are compensated for in subsequent data reduction and normalization.

\section{Stable Isotope Analyses-Collagen}

Approximate $0.6 \mathrm{mg}$ samples of collagen were weighed into tin capsules for stable isotope measure- 
ments $\left({ }^{13} \mathrm{C}\right.$ and ${ }^{15} \mathrm{~N}$ and $\mathrm{C} / \mathrm{N}$ ratio) using a continuous-flow isotope ratio mass spectrometer (Thermo Scientific Delta V Advantage, Bremen, Germany) coupled to a Costech ECS 4010 elemental analyzer (EA) (Milan, Italy) fitted with a pneumatic autosampler. The EA is coupled to the mass spectrometer via a ConfloIVTM and the samples are combusted in a single reactor containing tungstic oxide and copper wires at $1020^{\circ} \mathrm{C}$ to produce $\mathrm{N}_{2}$ and $\mathrm{CO}_{2}$. The gases are separated in a 2-m stainless steel Porapak QS 50-80 mesh GC column heated to $70^{\circ} \mathrm{C}$. Helium $(100 \mathrm{~mL} / \mathrm{min})$ is used as a carrier gas throughout the procedure. $\mathrm{N}_{2}$ and $\mathrm{CO}_{2}$ enter the mass spectrometer via an open split arrangement within the ConfloIV and are analyzed against their corresponding reference gases. For every 10 unknown samples, in-house gelatin standards, which are calibrated to the international reference materials USGS40, USGS41, IAEA-CH-6, USGS25, IAEA-N-1 and IAEA-N-2, are run in duplicate. Results are reported as per mil (\%) relative to the internationally accepted standards V-PDB and AIR with $1 \sigma$ precisions of $\pm 0.2 \%$ and $\pm 0.3 \%$ for $\delta^{13} \mathrm{C}$ and $\delta^{15} \mathrm{~N}$, respectively. Any results for bone samples that have molar $\mathrm{C} / \mathrm{N}$ ratios outside the range of 2.9-3.6 would be discarded as they would be deemed to represent collagen that has undergone postdepositional alteration (DeNiro 1985).

\section{Stable Isotope Analyses-Enamel}

A subsample of the $\mathrm{CO}_{2}$ derived from hydrolysis of the enamel fractions was used for $\delta^{13} \mathrm{C}$ measurement using a VG Sira 10 isotope ratio mass spectrometer with NBS 22 (oil) and NBS 19 (marble) employed as standards. Results are again reported as per mil (\%) relative to the internationally accepted standard V-PDB with a $1 \sigma$ precision of $\pm 0.1 \%$.

\section{RESULTS AND DISCUSSION}

All sample yields and stable isotope and ${ }^{14} \mathrm{C}$ results are presented in Table 1. The collagen samples had $\mathrm{C} / \mathrm{N}$ ratios between 3.1 and 3.3, which are well within the range that is indicative of no postdepositional alteration (DeNiro 1985); therefore, the samples were deemed suitable for ${ }^{14} \mathrm{C}$ analysis. The ${ }^{14} \mathrm{C}$ results are presented as fraction modern values $\left(\mathrm{F}^{14} \mathrm{C}\right) \pm 1 \sigma$ (Reimer et al. 2004). Calibration was undertaken using CALIBomb (Reimer and Reimer 2004) and the Northern Hemisphere Zone 1 data set (Hua et al. 2013).

Table 1 Sample yields, ${ }^{14} \mathrm{C}$ fraction modern $\left(\mathrm{F}^{14} \mathrm{C}\right)$ and stable isotope values for bone and teeth samples.

\begin{tabular}{|c|c|c|c|c|c|c|}
\hline Sample type & $\begin{array}{l}\text { Sample } \\
\text { size }(\mathrm{g})\end{array}$ & $\begin{array}{l}\text { Yield of } \\
\text { enamel or } \\
\text { collagen }(\mathrm{g})\end{array}$ & $\begin{array}{l}\text { Fraction modern } \\
\left(\mathrm{F}^{14} \mathrm{C} \pm 1 \sigma\right)\end{array}$ & $\begin{array}{l}\delta^{13} \mathrm{C}(\%) \\
\text { relative to } \\
\text { VPDB }\end{array}$ & $\begin{array}{l}\delta^{15} \mathrm{~N}(\%) \\
\text { relative } \\
\text { to AIR }\end{array}$ & $\begin{array}{l}\mathrm{C} / \mathrm{N} \\
\text { ratio }\end{array}$ \\
\hline Femur (cortical bone collagen) & 1.09 & 0.23 & $1.4673 \pm 0.0064$ & -18.2 & 11.6 & 3.2 \\
\hline $\begin{array}{l}\text { Vertebra (trabecular bone col- } \\
\text { lagen) }\end{array}$ & 4.61 & 1.04 & $1.5247 \pm 0.0047$ & -18.7 & 12.3 & 3.2 \\
\hline Lower canine (crown enamel) & 0.72 & 0.31 & $1.0246 \pm 0.0037$ & -11.5 & $\mathrm{n} / \mathrm{a}$ & $\mathrm{n} / \mathrm{a}$ \\
\hline Lower canine (root collagen) & 0.34 & 0.08 & $1.3687 \pm 0.0041$ & -17.6 & 12.1 & 3.3 \\
\hline $\begin{array}{l}\text { Lower 2nd incisor (crown } \\
\text { enamel) }\end{array}$ & 0.33 & 0.15 & $0.9945 \pm 0.0036$ & -11.8 & $\mathrm{n} / \mathrm{a}$ & $\mathrm{n} / \mathrm{a}$ \\
\hline Lower 2nd incisor (root collagen) & 0.33 & 0.05 & $1.1859 \pm 0.0043$ & -17.6 & 12.4 & 3.2 \\
\hline $\begin{array}{l}\text { Upper right } 3 \text { rd molar (crown } \\
\text { enamel) }\end{array}$ & 0.98 & 0.26 & $1.6092 \pm 0.0058$ & -11.4 & $\mathrm{n} / \mathrm{a}$ & $\mathrm{n} / \mathrm{a}$ \\
\hline $\begin{array}{l}\text { Upper right 3rd molar (root } \\
\text { collagen) }\end{array}$ & 0.60 & 0.06 & $1.5328 \pm 0.0039$ & -18.1 & 12.5 & 3.1 \\
\hline
\end{tabular}

\section{Teeth}

Qualitatively, the results indicate the following: 
1. The measured fraction modern values of all samples are indicative of someone who was living post-1955 when $\mathrm{F}^{14} \mathrm{C}$ values in the atmosphere exceeded 1.

2. The $\mathrm{F}^{14} \mathrm{C}$ value for the crown enamel of the lower 2 nd incisor $(0.9945 \pm 0.0036)$ is too high to be pre-modern, as defined by Taylor et al. (1989) and implies that enamel formation commenced prior to 1955 and continued for a short time after that date. On the basis that crown development is completed by the age of 4-5 yr old (Ash and Nelson 2003) (Table 2), this would imply that commencement was around 1952-1953 and this would approximate to the year of birth. The root collagen $\mathrm{F}^{14} \mathrm{C}$ value for this tooth is $1.1859 \pm 0.0043$. This indicates that root formation occurred largely within the bomb period. This period has to be pre-1963; otherwise, the $\mathrm{F}^{14} \mathrm{C}$ value would be much higher. On the basis that root formation is completed around $5 \mathrm{yr}$ after enamel formation, this value is entirely consistent with the enamel value.

3. The lower canine crown enamel $\mathrm{F}^{14} \mathrm{C}$ value of $1.0246 \pm 0.0037$ is again indicative of a tooth whose crown formation commenced before 1955 and continued into the bomb period. On the basis that crown formation is complete by 6-7 yr of age (Ash and Nelson 2003), this would imply that crown formation again commenced around 1952-1953. The root collagen value of $1.3687 \pm 0.0041$ is again indicative of root formation that occurred largely within the bomb period. Again, this period would have commenced pre-1963, otherwise the $\mathrm{F}^{14} \mathrm{C}$ value would be much higher. On the basis that root formation is completed around $7 \mathrm{yr}$ after enamel formation, this is again entirely consistent.

4. The higher $\mathrm{F}^{14} \mathrm{C}$ value of canine root collagen compared with incisor root collagen is consistent with canine root completion occurring after the incisor root. This trend also applies to the enamel values where canine crown development is completed after incisor crown completion.

5. Since the crown enamel $\mathrm{F}^{14} \mathrm{C}$ value of the $3 \mathrm{rd}$ molar is higher than that of the root collagen, this demonstrates that the values lie on the downslope of the peak (post-1963).

6. The stable isotope values for all collagen samples (tooth and bone) are higher than would be expected for someone subsisting on a purely terrestrial diet, implying some consumption of nonterrestrial resources, probably marine, which would lead to reduced ${ }^{14} \mathrm{C}$ activities in human remains due to the marine reservoir effect.

Table 2 Times of commencement and completion of crown and root development in the teeth analyzed.

\begin{tabular}{lllll}
\hline Tooth & $\begin{array}{l}\text { Calcification } \\
\text { commences* }\end{array}$ & $\begin{array}{l}\text { Crown development } \\
\text { completed* }\end{array}$ & $\begin{array}{l}\text { Lifetime of crown } \\
\text { development }\end{array}$ & $\begin{array}{l}\text { Root development } \\
\text { completed* }\end{array}$ \\
\hline Canine & $4-5$ months & $6-7 \mathrm{yr}$ & $6.1 \mathrm{yr}$ approx. & $12-14 \mathrm{yr}$ \\
2nd incisor & $3-4$ months & $4-5 \mathrm{yr}$ & $4.2 \mathrm{yr}$ approx. & $10 \mathrm{yr}$ \\
3rd molar & $7-9 \mathrm{yr}$ & $12-16 \mathrm{yr}$ & $3 \mathrm{yr}$ (minimum) & $18-25 \mathrm{yr}$ \\
3rd molar & $7-9 \mathrm{yr}$ & $12-16 \mathrm{yr}$ & $9 \mathrm{yr}$ (maximum) & $18-25 \mathrm{yr}$ \\
\hline
\end{tabular}

*From Ash and Nelson (2003).

A more quantitative approach through calibration of the $\mathrm{F}^{14} \mathrm{C}$ results using CALIBomb (Reimer and Reimer 2004) and the Northern Hemisphere Zone 1 data set (Hua et al. 2013) was also carried out as follows. Calibrations of the teeth results were carried out using two methods. In Method 1, the length of time of crown or root development was used as the smoothing term (i.e. the lifetime of the sample). Assuming a linear increase in development, the time taken to lay down $50 \%$ was calculated using the data in Table 2. From this, the time from birth was calculated and subtracted from the calibrated age range determined by CALIBomb to produce a year-of-birth range. For example, for 
the lower canine, the average age at which the crown is complete is $6.5 \mathrm{yr}$. However, the average age at which initial calcification commenced is $0.4 \mathrm{yr}$. Therefore, the crown forms over a period of just over $6.1 \mathrm{yr}$; hence, the time for $50 \%$ formation of the crown is just under $3.1 \mathrm{yr}$, which is therefore just over $3.5 \mathrm{yr}$ from birth. The results are presented in Table 3.

Table 3 Year of birth calculations using CALIBomb for lower canine and lower lateral incisor. The duration of crown or root formation is used as the smoothing term (Method 1).

\begin{tabular}{|c|c|c|c|c|c|}
\hline Tooth analyzed & $\begin{array}{l}\text { Average age } \\
\text { at initial calci- } \\
\text { fication }\end{array}$ & $\begin{array}{l}\text { Average age at } \\
\text { crown or root } \\
\text { completion }\end{array}$ & $\begin{array}{l}\text { Time of } 50 \% \\
\text { completion } \\
\text { relative to birth }\end{array}$ & Calibrated age & $\begin{array}{l}\text { Year of birth } \\
\text { (calibrated } \\
\text { age-column 4) }\end{array}$ \\
\hline $\begin{array}{l}\text { Lower canine } \\
\text { enamel }\end{array}$ & $0.4 \mathrm{yr}$ & $6.5 \mathrm{yr}$ & $3.5 \mathrm{yr}$ approx. & $1953.5-1954.5$ & $1950-1951$ \\
\hline $\begin{array}{l}\text { Lower canine root } \\
\text { collagen }\end{array}$ & $0.4 \mathrm{yr}$ & $13.0 \mathrm{yr}$ & $6.7 \mathrm{yr}$ approx. & 1958.1-1961.1 & 1951-1954 \\
\hline $\begin{array}{l}\text { Lower } 2 \text { nd incisor } \\
\text { enamel }\end{array}$ & $0.3 \mathrm{yr}$ & $4.5 \mathrm{yr}$ & 2.4 yr approx. & $\begin{array}{l}1695-1726 \\
1813-1839 \\
1841-1854 \\
1859-1861 \\
1867-1918 \\
1952-1955\end{array}$ & $1950-1953$ \\
\hline $\begin{array}{l}\text { Lower } 2 \text { nd incisor } \\
\text { root collagen }\end{array}$ & $0.3 \mathrm{yr}$ & $10 \mathrm{yr}$ & 5.2 yr approx. & $\begin{array}{l}1956.6-1958.9 \\
1986.2-1987.4\end{array}$ & $\begin{array}{l}1951-1954 \\
1981-1982\end{array}$ \\
\hline
\end{tabular}

Calculation of year of birth on the basis of the results for the lower canine enamel and root collagen produce very similar ranges of 1950-1951 and 1951-1954, respectively. The lower 2nd incisor enamel analysis resulted in several age ranges. All of those between 1695 and 1918 can be ignored on the basis that the root collagen result indicates a post-1955 age. This leaves a single credible age range of 1950-1953. The root collagen analysis indicates two possible age ranges of 1981-1982 and 1951-1954. The latter is completely in agreement with the other results. Therefore, these results all point to a year of birth between 1950 and 1954.

In Method 2, again, the time for $50 \%$ completion of the root or crown relative to the birth year was subtracted from the calibrated age range to produce a year of birth range. The only difference from Method 1 was that no smoothing term was employed. The results are shown in Table 4. Calibration of the lower canine enamel produces an age of birth range of 19521953, while the lower 2nd incisor enamel produces a range of 1950-1953. The root collagen results are much less satisfactory, giving several possible ranges. We would propose that this is due to the lack of a smoothing term for the long formation times of the roots. The 3rd molar results were not calibrated as it was felt that the initiation and completion of crown and root developments were too variable to be useful.

\section{Bone}

The study results show that the $\mathrm{F}^{14} \mathrm{C}$ values in the trabecular $(1.5247 \pm 0.0047)$ and cortical bone $(1.4673 \pm 0.0064)$ are very similar, which, on the basis of the conclusions of Ubelaker and Parra (2011), would imply that this was a young person. Calibration of the bone collagen results was again carried out using CALIBomb to establish a year of death. With no smoothing term, the trabecular bone from the vertebra calibrated to 1963 or 1969-1972. The former age can be disregarded on the basis of our estimation of year of birth as this would make the person around 10-12 yr old and we know that the 3rd molar was fully formed; hence, the remains could not belong to someone as young as this. 
Table 4 Year-of-birth calculations using CALIBomb for lower canine and lower lateral incisor. No smoothing term was used. Again, the time of $50 \%$ completion of the crown or root relative to birth was subtracted from the calibrated age to produce a year of birth (Method 2).

\begin{tabular}{|c|c|c|c|c|c|}
\hline Tooth analyzed & $\begin{array}{l}\text { Average } \\
\text { age at initial } \\
\text { calcification }\end{array}$ & $\begin{array}{l}\text { Average age at } \\
\text { crown or root } \\
\text { completion }\end{array}$ & $\begin{array}{l}\text { Time of } 50 \% \\
\text { completion rela- } \\
\text { tive to birth }\end{array}$ & Calibrated age & $\begin{array}{l}\text { Year of birth } \\
\text { (calibrated age- } \\
\text { column 4) }\end{array}$ \\
\hline $\begin{array}{l}\text { Lower canine } \\
\text { enamel }\end{array}$ & $0.4 \mathrm{yr}$ & $6.5 \mathrm{yr}$ & 3.5 yr approx. & $1955.4-1956.9$ & $1952-1953$ \\
\hline $\begin{array}{l}\text { Lower canine } \\
\text { root collagen }\end{array}$ & $0.4 \mathrm{yr}$ & $13 \mathrm{yr}$ & $6.7 \mathrm{yr}$ approx. & $\begin{array}{l}1962.3-1962.8 \\
1974.7-1976.7 \\
1977.5\end{array}$ & $\begin{array}{l}1956 \\
1969 \\
1971\end{array}$ \\
\hline $\begin{array}{l}\text { Lower 2nd } \\
\text { incisor enamel }\end{array}$ & $0.3 \mathrm{yr}$ & $4.5 \mathrm{yr}$ & 2.4 yr approx. & $\begin{array}{l}1695-1726 \\
1813-1839 \\
1841-1854 \\
1859-1861 \\
1867-1918 \\
1952-1955\end{array}$ & 1950-1953 \\
\hline $\begin{array}{l}\text { Lower } 2 \text { nd } \\
\text { incisor root } \\
\text { collagen }\end{array}$ & & $10 \mathrm{yr}$ & $5.2 \mathrm{yr}$ approx. & $\begin{array}{l}1958.4-1959.2 \\
1960.0 \\
1985.0-1985.2 \\
1985.8-1988.8\end{array}$ & $\begin{array}{l}1953-1954 \\
1955 \\
1980 \\
1981-1984\end{array}$ \\
\hline
\end{tabular}

Similarly, for the cortical bone, calibration indicates a year of death of either 1963 or 1971-1974. The former age can again be ruled out on the same basis as described for the trabecular bone. In this study, the results point to the trabecular bone lagging the cortical bone by about a year, which is contrary to that expected given the results from the Ubelaker et al. (2006) study. This is perhaps understandable given that we analyzed a femur and a vertebra. In hindsight, analysis of trabecular and cortical bone collagen from the femur would have been a better option. Overall, the results point to a year of death between 1969 and 1974.

Table 5 Year of death calculations using CALIBomb.

\begin{tabular}{lll}
\hline Bone & Fraction modern & Calibrated age range \\
\hline Femur (cortical bone) & $1.4673 \pm 0.0064$ & 1963 or $1971-1974$ \\
Vertebra (trabecular bone) & $1.5247 \pm 0.0047$ & 1963 or $1969-1972$ \\
\hline
\end{tabular}

One complicating factor in these arguments is the fact that the $\delta^{13} \mathrm{C}$ values are quite high and would indicate consumption of resources other than those based on terrestrial $\mathrm{C}_{3}$ plants at the base of the food chain. This could include marine fish/shellfish, freshwater fish, and resources based on $\mathrm{C}_{4}$ plants. Even though the remains are of someone born around $60 \mathrm{yr}$ ago, $\mathrm{a}_{4}$ plant contribution (directly or indirectly) cannot be totally ignored. For example, a large proportion of tinned corned beef, which was very popular when fresh beef was scarce, came from South America where $\mathrm{C}_{4}$ plants can be abundant in pasture land (Powell and Still 2009). Freshwater resources can, in some water bodies, have a reservoir age (Cook et al. 2001; Keaveney and Reimer 2012), although the quantities consumed would typically form a very small part of the average diet. Marine fish and shellfish would be the most likely nonterrestrial resource and the fact that the $\delta^{15} \mathrm{~N}$ values are also high would tend to support this. Consumption of marine resources would introduce a marine reservoir effect, i.e. the ${ }^{14} \mathrm{C}$ activity would be reduced compared with contemporaneous terrestrially based resources. Georgiadou and Stenström (2010) demonstrated that a human diet containing a "normal fraction of 
food of marine origin" has the potential to influence dating within the bomb period by a few years ( $<3$ yr using typical diets and for the populations they studied). Fortunately, for this study, the remains are of someone who was born prior to the time when $\mathrm{F}^{14} \mathrm{C}$ values were in excess of 1 and who died after the maximum $\mathrm{F}^{14} \mathrm{C}$ value in 1963. If it is assumed that the $\delta^{13} \mathrm{C}$ values of the teeth collagen are indicative of a marine dietary component, then the year of birth would be more recent than calculated (the $\mathrm{F}^{14} \mathrm{C}$ value would be higher in the absence of a marine contribution). Similarly, the values in the bone collagen (on the downslope of the bomb peak) would be increased in the absence of a marine component, which would shift the year of death to an earlier year. Thus, in both cases, the effect is to reduce the age of the person at death.

\section{CONCLUSIONS}

The results of both our qualitative and quantitative analyses of teeth results suggest that the year of birth of this person was between 1950 and 1954 and the year of death was between 1969 and 1974. This would make the maximum age range around 15 to $24 \mathrm{yr}$. Analyses of the dentition and other skeletal parameters can eliminate the younger part of the range so an age of around 18 to $24 \mathrm{yr}$ at death would seem most likely. Taking any potential marine effect into account could reduce this age range to around 18 to $21 \mathrm{yr}$. However, it should be stressed that the year of death conclusion is based on a single study (Ubelaker and Parra 2011) where samples from only four individuals were analyzed. This obviously highlights a requirement for more extensive research into the relationship between trabecular and cortical bone and atmospheric ${ }^{14} \mathrm{C}$ levels from different areas of the skeleton. Despite an extensive investigation by the Greater Manchester Police, including international enquiries, to date, the identification of the female and the circumstances surrounding her death have still not been established.

\section{ACKNOWLEDGMENTS}

The authors would like to thank Greater Manchester Police's Cold Case Review Unit for their permission to use the details of this case and the staff of the SUERC AMS facility for measuring the samples.

\section{REFERENCES}

Ash MM, Nelson SJ. 2003. Wheeler's Dental Anatomy, Physiology, and Occlusion. 8th edition. Philadelphia: W.B. Saunders.

Cook GT, MacKenzie AB. 2014. Radioactive isotope analyses of skeletal materials in forensic science: a review of uses and potential uses. International Journal of Legal Medicine 128(4):685-98.

Cook GT, Bonsall C, Hedges REM, McSweeney K, Boroneant V, Pettitt PB. 2001. A freshwater dietderived reservoir effect at the Stone Age sites in the Iron Gates gorge. Radiocarbon 43(2A):453-60.

Cook GT, Dunbar E, Black SM, Xu S. 2006. A preliminary assessment of age at death determination using the nuclear weapons testing ${ }^{14} \mathrm{C}$ activity of dentine and enamel. Radiocarbon 48(3):305-13.

DeNiro MJ. 1985. Postmortem preservation and alteration of in vivo bone collagen isotope ratios in relation to palaeodietary reconstruction. Nature 317(6040):806-9.

Georgiadou E, Stenström K. 2010. Bomb-pulse dating of human material: modeling the influence of diet. Radiocarbon 52(2):800-7.
Hua Q, Barbetti M, Rakowski AJ. 2013. Atmospheric radiocarbon for the period 1950-2010. Radiocarbon 55(4):2059-72.

Keaveney E, Reimer PJ. 2012. Understanding the variability in freshwater radiocarbon reservoir offsets: a cautionary tale. Journal of Archaeological Science 39(5):1306-16.

Longin R. 1971. New method of collagen extraction for radiocarbon dating. Nature 230(5291):241-2.

Mays S. 1998. The Archaeology of Human Bones. London: Routledge.

Powell RL, Still CJ. 2009. Biogeography of $\mathrm{C}_{3}$ and $\mathrm{C}_{4}$ vegetation in South America. In: Anais XIV Simpósio Brasileiro de Sensoriamento Remoto, Natal, Brasil, 25-30 April 2009. INPE. p 2935-42.

Reimer R, Reimer P. 2004. CALIBomb - calibration of post-bomb ${ }^{14} \mathrm{C}$ data. URL: http://calib.qub.ac.uk/ CALIBomb/.

Reimer PJ, Brown TA, Reimer RW. 2004. Discussion: reporting and calibration of post-bomb ${ }^{14} \mathrm{C}$ data. $R a$ diocarbon 46(3):1299-304.

Reventlid M, Mörnstad H, Teivens A. 1996. Intra- and 
inter-examiner variations in four dental methods for age estimation of children. Swedish Dental Journal 20(4):133-9.

Scheuer L, Black S. 2000. Developmental Juvenile Osteology. London: Elsevier.

Slota Jr PJ, Jull AJT, Linick TW, Toolin LJ. 1987. Preparation of small samples for ${ }^{14} \mathrm{C}$ accelerator targets by catalytic reduction of CO. Radiocarbon 29(2):303-6.

Spalding KL, Buchholz BA, Bergman L-E, Druid H, Frisen J. 2005. Age written in teeth by nuclear tests. Nature 437(7057):333-4.

Taylor RE, Suchey JM, Payen LA, Slota PJ Jr. 1989. The use of radiocarbon $\left({ }^{14} \mathrm{C}\right)$ to identify human skeletal materials of forensic science interest. Journal of $\mathrm{Fo}$ - rensic Science 34(5):1196-205.

Ubelaker DH, Parra RC. 2011. Radiocarbon analysis of dental enamel and bone to evaluate date of birth and death: perspective from the Southern Hemisphere. Forensic Science International 208(1-3):103-7.

Ubelaker DH, Buchholz BA, Stewart JEB. 2006. Analysis of artificial radiocarbon in different skeletal and dental tissue types to evaluate date of death. Journal of Forensic Science 51(3):484-8.

Vandeputte K, Moens L, Dams R. 1996. Improved sealed-tube combustion of organic samples to $\mathrm{CO}_{2}$ for stable isotope analysis, radiocarbon dating and percent carbon determinations. Analytical Letters 29(15):2761-73. 